Matthias Premer

Grundzüge der Volkswirtschaftslehre 

Matthias Premer

\section{Grundzüge der Volkswirtschaftslehre}

Makroökonomik und Mikroökonomik

2., aktualisierte Auflage 
ISBN 978-3-486-76378-2

e-ISBN (PDF) 978-3-11-041391-5

e-ISBN (EPUB) 978-3-11-042376-1

Library of Congress Cataloging-in-Publication Data

A CIP catalog record for this book has been applied for at the Library of Congress.

\section{Bibliografische Information der Deutschen Nationalbibliothek}

Die Deutsche Nationalbibliothek verzeichnet diese Publikation in der Deutschen Nationalbibliografie; detaillierte bibliografische Daten sind im Internet über

http://dnb.dnb.de abrufbar.

(C) 2015 Walter de Gruyter GmbH, Berlin/Boston

Druck und Bindung: CPI books GmbH, Leck

$\otimes$ Gedruckt auf säurefreiem Papier

Printed in Germany

www.degruyter.com 